\title{
NÁRAY-SZABÓ SÁNDOR REFORMTEVÉKENYSÉGE ÉS HATÁSA A SZEGEDI ÉS A DEBRECENI GYÓGYPEDAGÓGIAI INTÉZETEKRE
}

Szerzők:

Varga Imre

Szegedi Tudományegyetem

Hatos Gyula

Első szerző e-mail címe:

varga.phdr@gmail.com

\section{Lektorok:}

Koncz István

Professzorok az Európai Magyarországért

Mező Ferenc

Debreceni Egyetem

Mező Katalin

Debreceni Egyetem

Schéder Veronika

Debreceni Egyetem

Hatos Gyula és Varga Imre (2015): Náray-Szabó Sándor reformtevékenysége és hatása a szegedi és a debreceni gyógypedagógiai intézetekre, Különleges Bánásmód, I. évf. 2015/1. szám, 7-24 DOI 10.18458/KB.2015.1.7

\begin{abstract}
Absztrakt
Jelen tanulmány a XX. századi magyar gyógypedagógia megalapozójának, Dr. NáraySzabó Sándornak a munkáját és jelentöségét összegzi. Náray-Szabó (1861-1914) a XIX. század végén század elején felismerte a társadalmi lehetöségeket, s a fogyatékos személyek iskoláinak és a tanáraik képzésének megreformálása érdekében dolgozott. Ö volt a modern magyar gyógypedagógia egyik megalapítója.
\end{abstract}

Kulcsszavak: Náray-Szabó Sándor, gyógypedagógia

Diszciplina: gyógypedagógia

\begin{abstract}
REFORMING THE TEACHER TRAINING OF THOSE WHO WORK WITH CHILDREN WITH SPECAIL EDUCATIONAL NEEDS IN DEBRECEN AND SZEGED INSTITUTIONS

This study summarizes the work and significance of Dr. Sándor Náray-Szabo, who was the founder of the Hungarian special education in the 20th. century. At the end of 19th century, Náray-Szabó (1861-1914) recognized the social opportunities, and he worked in order to reform schools and the teacher training of disabled people. He was one of the founders of the modern Hungarian education system for those with special educational needs.
\end{abstract}

Keywords: Sándor Náray-Szabó, special educational needs

Discipline: special educational needs 
„A jó tanítás interaktív, egyénileg vonja be a gyereket a folyamatba, s minden érzékre hat, vagyis megfelel a gyerek személyiségének."

Malcom Gladwell

Napjainkban emlékezünk a magyar történelem egyik nagy megpróbáltatásának kezdetére, az első világháború kitörésére, amelynek következményei 20. századi történelmünkre kihatottak. Tanulmányunk fókuszában egy olyan kiemelkedő gyógypedagógia-történeti személyiség áll, aki a 19. és 20. század fordulóján felismerte a társadalmi lehetőségeket a fogyatékos személyek iskoláztatásának intézményes megteremtésére és a fogyatékos gyermekeket képző speciális tudású pedagógusok felsőfokú képzésének létrehozására.

\section{Történeti áttekintés}

A magyar közoktatási intézmények közé a siketnéma gyermekek oktatására szolgáló iskola lépett be elsőnek a 19. század első éveiben. Ezt a történelmi kort, a reformkort, kiemelkedő személyiségek, alkotások jellemezték.

Cházár András (1. kép), a gömöri szolgabíró Bécsben szerzett tapasztalatai alapján ekkor teremtette meg hazánkban is a siket gyermekek iskoláját. Huszonöt év elteltével nyitottak iskolát más fogyatékos gyermekeknek, immár a vakoknak Pozsonyban, majd Pesten a második intézményt. A magyar társadalom világi és egyházi körei nemzeti ügynek fogadták ezeket az alapításokat. Nagy értékü alapítványi vagyon jutott a két országos intézetnek száz esztendőn keresztül (Simon, 1937). De sokáig, a 20. századba átnyúlóan is késett a fontos lépés, a tankötelezettség és a kötelező iskolaállítás megoldása. A 19. század nagy nemzeti történései, a szabadságharc, a kiegyezés sem érintette a siketnémák országos, sem a vakok királyi intézetét. De megfeledkeztek róla az 1867-es népoktatási törvény alkotói, a testileg vagy szellemileg gyenge gyermekek felmentést kaptak az iskolába járás alól, a „taníthatatlan tompaelméjüeket” pedig kizárták az iskolákból. 1875-ben azért magánkezdeményezésre megalakult a súlyosan értelmi fogyatékosok intézete, majd 1877-ben az izraelita siketnémák intézete. A századfordulón tehát alig volt iskola, intézet az Osztrák-Magyar Monarchia magyar királysági részében a fogyatékos gyermekek számára.

1. kép: Jólészi Cházár András, a siketnéma-gondozás előharcosa Magyarországon. (Történelmi képcsarnok: az eredeti rézmetszet mérete $11 \times 15.5 \mathrm{~cm}$. Jelzése: Gyurkovist (így!) Pinx. Budae. Prixner sc. Pestini. Megjelent az Annales Evangelici IX. kötetében, Budán, 1803-ban.)

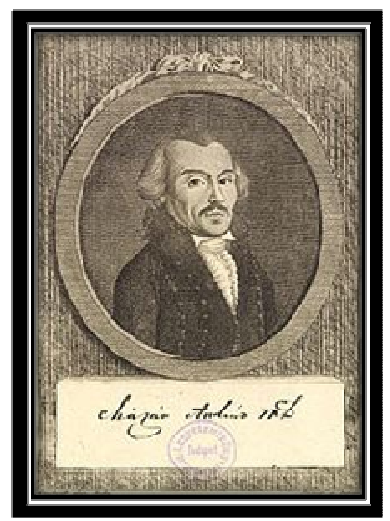


Az 1890-es évek elején a források 2 siketnéma intézetet említenek körülbelül 100-100 növendékkel és két iskolát kb. 15-15 növendékkel. A vak/látássérült személyek számára egy intézet, a súlyosabban sérült értelmi fogyatékosok számára egy magánintézet müködött kb. 60 gyermekkel. Ez nem volt sem iskolahálózat, sem iskolarendszer. Szervezetileg a „a jótékony intézetek" körébe sorolták őket (az 1848-as egyetemes tanügyi kongresszuson, mint megfigyelök voltak jelen, javaslatokat is tettek, de hatásuk később sem mutatkozott). A század második felében a közoktatás szervezésében az „emberbaráti intézetek” elnevezés alá sorolták e pár iskolát, így szerepeltek a millenniumi egyetemes tanügyi kongresszuson is (1896). Egy résztvevő, a magyar gyógypedagógia történek kiemelkedő alakja, Herodek Károly (2. kép) emlékezésében erről azt írja: ,... összeházasítottak bennünket az árva és szeretetházak és ehhez hasonló egyéb nevelőintézetek szakembereivel...”. Miután ezeket az intézeteket és a siket és vak, gyengeelméjü gyermekek intézeteit is jelentősen adományokból tartották fenn, közel állt a gondolat, hogy a fogyatékosok iskoláit is „ezzel az elnevezéssel illessék, illetőleg e cím alá bujtassák”. Tovább folytatja Herodek: ,... a határozati javaslatok végső csattanója az volt, hogy a két kategória külön választassék, és az érzékszervi, valamint az értelmi fogyatékosok ügyével foglalkozó szakemberek külön csoportban tárgyalhassák meg ügyeiket"

2. kép: Herodek Károly gyógypedagógus, a Vakok József Nádor Királyi Országos Intézete igazgatója

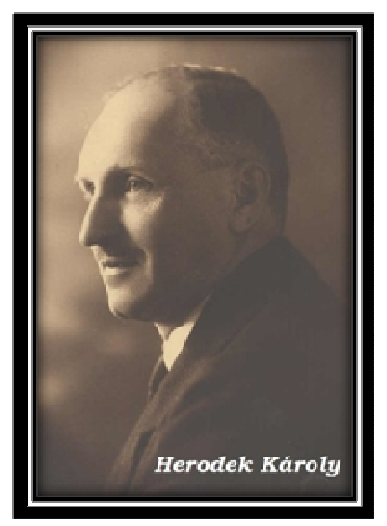

Kemény harcok után a kongresszus elismerte a fogyatékosok tanárainak különválását, és mint Herodek Károly $(1933,97$.$) írja: „Talán nem járok messze attól a gondolattól, ha állítom,$ hogy ez a körülmény szülte a »gyógypedagógia« elnevezést”.

\section{Náray-Szabó Sándor - reformer a 19. század végén}

A fogyatékos gyermekekkel foglalkozó intézetek állami intézkedéseket kívánó ügyei a 19. század második felében közvetlenül a vallás és közoktatásügyi minisztérium irányítása alá tartoztak, az „emberbaráti intézmények” körében. Ekkor már a tanárok külön keretek megállapításáért harcoltak és az első csatát 1896-ban meg is nyerték. Ezt megelőzően, 1886ban került a minisztériumba egy fiatal orvos, fogalmazó gyakornokként, aki gyakran járt az 
intézetekben, megismerte őket, tanulóikat, tanáraikat és ezek az élmények egész életére a fogyatékos emberekhez kapcsolódó tevékenységhez kötötték. Ki ez az ember, akit kortársai halálakor úgy jellemeztek, mint „a magyar gyógyító pedagógia megteremtőjét” (Vértes, 1915; vö.: 3. kép).

\section{3. kép: Náray-Szabó Sándor, a magyar gyógyító pedagógia megteremtöje}

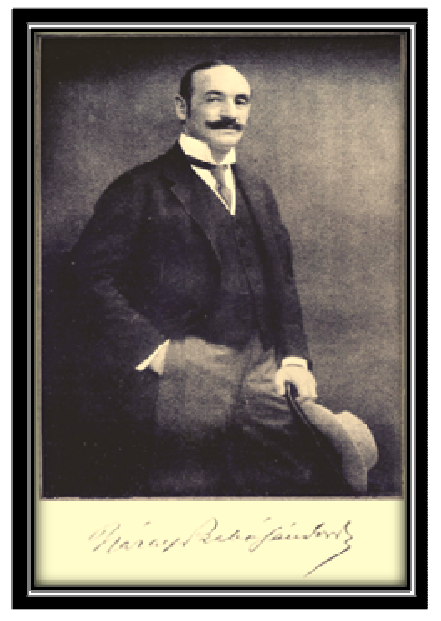

Náray-Szabó Sándor élete a 19. század hazáért lelkesedő, tenni tudó családjában kezdődött. Az akkor még nemesi előnévvel jelzett nárai Szabó Sándor apja, nárai Szabó Miklós (az apa és fia névhasználata közötti különbségre magyarázat, hogy 1904-ig a „nárai” nemesi elönév gyanánt szerepelt, a tényleges családnév Szabó volt, ettől kezdve belügyminiszteri engedéllyel a Náray-Szabó kettős családnevet használhatták). Szombathelyen az egyik legismertebb ügyvéd volt, felesége bonyhádi Perczel Angéla tolna megyei föispán leánya.

Három gyermekük volt: két fiú és egy lány. Sándor fiuk Szombathelyen született, 1861. február 25-én. A három testvér között ő volt a legfiatalabb, gyenge szervezetü, vézna gyermek. Édesanyja négyéves korában meghalt, apja nevelte. A hatvanas évek közepén Szabó Miklós nagyon jól jövedelmező ügyvédi irodáját otthagyta és Pesten telepedett le, Deák Ferenc buzdítására és határozott kívánságára. Szabó Miklós szorgalmával a nemzet újjáébredésének hajnalán, az alkotmányos élet helyreállításának munkájában fontos szerepeket töltött be: volt igazságügyi államtitkár, a budapesti ítélőtábla, majd a magyar királyi kúria elnöke. Mindvégig szoros kapcsolatban volt a család Deák Ferenccel, a „haza bölcsével”, akit példaképének tekintett. Mint azt Náray-Szabó Sándor (1913) egy késői visszaemlékezésében írta „Ilyen példányképekben szerencsére bőségesen volt részem, s azok közvetlen hatását oly fokban érezhettem, mint ez csak keveseknek jut osztályrészül”.

Ugyanitt arról is szól, hogy Deák Ferenchez édesapját igaz benső kötelékek, mély barátság füzték. Gyakori együttlétük idején Deák kedélyes modorával, elmés kérdéseivel, meglepetésszerü tréfáival, kedves, fordulatos beszédével sokszor nehéz helyzetbe hozta. Deák Ferenc tréfáiról, szójátékairól, azután önfegyelméröl, egész példamutató magatartásáról részletesen is olvashatunk a Nemzet és emlékezet sorozatban megjelent kis kötetben (Sándor, 1986).

Mint Herodek Károly jellemezte később Náray-Szabó Sándort, nemes egyéniségének kialakulására kétségtelenül meghatározó befolyást gyakorolt az a magas intellektusú 
környezet és miliő, amely gyermekéveit jellemezte. Középiskolába a piaristák gimnáziumába járt, a nyári szünidőt külföldön töltötte, és később is sokat utazott, kitünően megtanult franciául és németül. Az orvosi egyetemre iratkozott be, itt Fodor József professzor mellett asszisztens lett a közegészségtani intézetben. 1885-ben avatták orvosdoktorrá, azonban nem lett gyakorló orvos. 1886. december 2-án Trefort miniszter (Trefort Ágoston 1817-1888, a 19. század kiemelkedő művelődés politikusa, a Deák párt tagja, 1872-tõl haláláig öt kormányban vallás- és közoktatási miniszter) ajánlatára, apja kívánságára a Vallás- és Közoktatásügyi Minisztériumban fogalmazó gyakornok lett, majd végigjárta a hivatali lépcsőket. 1888-tól kerül kapcsolatba a siketek intézetével. Miniszteri biztos, majd 1898-ban az akkor megalakult gyógypedagógiai ügyosztály vezetője lett.

Több jelentős esemény történt ebben az évben: Roboz József országos szakfelügyelö kiadja Magyar Gyógypedagógia folyóiratot, amelyben Dr. Náray-Szabó Sándor "Néhány szó a fogyatékosok oktatásügyéröl" címen megírja cikkét. Nyolc pontban foglalja össze mindazokat a kívánalmakat, amelyek érvényesítésével a fogyatékosok oktatásügye területén jelentékenyebb eredmény volna elérhető. Wlassics Gyula oktatásügyi miniszter rendeletben választja el a gyógypedagógiai intézeteket az emberbaráti intézetektől, és az intézménycsoportra bevezeti a ,gyógypedagógiai intézetek” megnevezést.

Új időszak kezdődik. Náray-Szabó dr. ekkor már ismerős ezekben az intézetekben, gyakran megfordult ott, tanításokat, vizsgákat látogatott, ismerte az ott folyó munkát, problémáikat. 1898-ban a meginduló Magyar Gyógypedagógia szakfolyóirathoz írt cikke már a jövő programját vázolta fel. A fogyatékosok oktatásügyének eredményei nem maradtak el, munkásságát feljebbvalói felismerték, értékelték, ennek köszönhette, hogy gyorsan haladt a ranglétrán. 1906-ban elnöki titkár, ugyanazon évben címzetes miniszteri tanácsos lett. 1911. december 2-án a gyógypedagógiai intézetek megünnepelték Náray-Szabó Sándor közszolgálatának 25. évfordulóját, számba véve munkássága eredményeit. Ezután már csak pár rövid évre futotta életéből. Dr. Náray-Szabó Sándor önzetlen, kötelességtudó, fegyelmezett, becsületes és szerény munkásságának köszönhetően igyekezett a hazai gyógypedagógiai oktatásügy pilléreit lerakni Magyarországon. A király 1912-ben a kultuszminisztérium államtitkárává nevezte ki, de már egy év múlva nyugdíjba ment, és a háború első hónapjaiban - száz évvel ezelőtt - 1914. november 18-án meghalt. Az intézmények, amelyek munkássága nyomán szerveződtek, a tanárok és tanulók megőrizték az emlékét a következő évtizedekben. „Semmi kétség az iránt és ezt teljes objektivitással megállapítjuk mi, de megállapítják mindazok, akik müködését ismerték és azzal foglalkoztak, hogy Dr. Náray-Szabó Sándor a magyar gyógypedagógia megteremtője (kiemelés tőlünk Hatos Gy., Varga I.), vezetője. Lelkes munkása volt, akinek nevével a magyar gyógypedagógia legújabb története és tudományos fejlődése szorosan összeforrott” (Herodek, 1933).

\section{A XX. századi magyar gyógypedagógia megalapozása}

Az emberbaráti intézetektől való, az egyetemes tanügyi kongresszuson történő elválás erősítette a fogyatékosok intézeteiben dolgozó szakemberek egymásra találását, számos személyi és szervezeti nehézség ellenére. A „Hogyan nevezzük magunkat?” - kérdésre is keresték a választ. Az akkori államszervezetben, az Osztrák-Magyar monarchiában kínálkozott megoldás, amire többen felfigyeltek, hiszen a vezető szakemberek szorgalmasan járták a külföldet, már a század elejétől kezdve. A Bécs melletti gyógyító-nevelőgondozó intézet vezetői 1861-ben jelentették meg Heilpädagogik címü munkájukat (inkább a súlyosabban sérült értelmi fogyatékosról szólt, de már jelezték az igényt, hogy a többi fogyatékos („nem egészséges”) gyermekre is gondoltak. 
Magyar szakemberek írásaiban is megjelent a szó tükörfordítása, használata. 1898-ban pedig Roboz József, már, mint elfogadott névvel indította az első szaklapot. A név új volt és elkülönítő, „egybefoglaló”, bár sokaknak nem tetszett. A 20. század folyamán tekintélyes szakemberek ragaszkodtak az általuk megfelelőbbnek tartott névhez, a „gyógyító-pedagógia”, „gyógyítva nevelés” elnevezésekhez. Ez a vita talán mind a mai napig - ha halkan is - itt van közöttünk. Náray-Szabó 1909-ben - az akkor még igen élénk - ellenvetések kapcsán így vélekedett: „Sokan kifogásolják a »Gyógypedagógia« elnevezést, mint ahogy az nem is egészen megfelelő. Egyrészt ugyanis nem magyaros, másrészt nem fedi teljesen azt az eljárást, mely a gyógyításhoz kötött közfogalomnak felel meg. Tényleg nem gyógyít; mindössze speciális tanítási eljárás segítségével lehetővé teszi azt, hogy egyes érzékek müködésbeli hiányát, vagy nagyobb fokú zavarát, más érzékek, illetve érzékszervek igénybevételével kiegyenlítsük” (Náray-Szabó, 1909, 1.). „Képesekké tehetjük a rászorult egyéneket arra, hogy külső behatások, vagy fejlődésbeli rendellenességek folytán nehezen hozzáférhetővé vált agybeli központjaik ingerületbe jöhessenek és az értelem élesztésére megkívánható módok alkalmazása által, közhasznú munkásságot végezhessenek. Minthogy azonban ezen eljárás csak élet- és bonctani, valamint psychológiai ismeretek birtokában lehet öntudatos és eredményes, mely eljárás alkalmazásával, ha nem is a szervi bajok gyógyítását, de társítás útján a fennállott működésbeli hiányosságnak mintegy orvoslását tényleg elérjük,... ez a magyarázata a »gyógypedagógia « elnevezésnek. (A gyógypedagógia fogalmáról ezekben az években további nagyon igényes, alapos tanulmányok jelentek meg, hogy csak kettőre utaljunk: Dr. Ranschburg Pál: Elmélkedések a gyógypedagógia jelenéről és jövőjéről. Magyar Gyógypedagógia, 1909. 4. és 7. sz. - benne a ,gyógypedagógia” fogalma fejezet -, valamint Dr. Vértes O. József: Gyógyító pedagógia fogalma és köre. Magyar Pedagógia, 1915)

A modern gyógypedagógia, annak jelen korlátolt extensivitású fejlettsége mellett, nem szolgálhat kizárólagosan egyes irányzatokat. Ez az indoka... a tanítóképzés egyesítésének" írja a továbbiakban -, majd annak a reményének ad hangot, hogy ,... mindazok, akiknek e tudományág fejlesztése igazán szívükön fekszik, összefognak; hogy az egységes gyógypedagógia ügyét (kiemelés tőlünk Hatos Gy. és Varga I.) felvirágoztassák ... Az összetartás erőt ad!" (Náray-Szabó, 1909, 1.). E sorokban megmutatkozik, hogy a századfordulón az állami vezetésben olyan szakember volt meghatározó szerepkörben, aki felismerte a szükségleteket, szakképzettségével, magas müveltségével és közéleti ismertségével, kapcsolataival, nem utolsó sorban együtt érző és támogató magatartásával a fogyatékos gyermekeket nevelő szakemberek ügyét eddig nem látott szinten támogatta. Széles látókörü gondolkodására, kultúrpolitikusi törekvéseire jellemző, hogy a fogyatékosok ügyét nem csak magában, hanem társadalmi szinten, szükebben a közoktatás keretei között, tágabban a társadalmi szociális fejlödés keretében, különösen a közegészségügy szintjén is előmozdítani akarta. Fentebb idézet cikkében kitér a közoktatásra, a tanító- és tanárképzésre is: „A gyógypedagógia körébe tartozó ismeretekre azonban nem csupán a kizárólag e szakmával foglalkozóknak van szükségük. Minden modern pedagógusnak ismernie kell a tanulók fontosabb testi- és szellemi rendellenességeit, melyek őket előrehaladásukban gátolni képesek. Ezt a pedagógiai tudomány újabb irányzata már szintén kénytelen elismerni és az oktatás terén nap-nap mellett felmerülő nehézségek, hova elöbb azt fogják eredményezni, hogy a tanító- és tanárképzést oly irányba kellene kiegészíteni, mely a jelzett ismeretekkel számol” (Náray- Szabó, 1909, 3.).

Náray-Szabó dr. tanulmányai során jó félévet gyakornokoskodott Fodor József professzor mellett az orvosegyetem közegészségtani intézetében, ahol már találkozott a népegészséget súlyosan károsító állapotokkal, azok következményeivel, éppen a fogyatékosságok létrejöttében, terjedésében, az embereket sújtó következményeivel. Mint Vértes O. József professzor $(1915,155$.) írta: „A nagy higiénikus hatása Náray-Szabó egész müködésén végighúzódik. S ha mesterétől el is válik, tanításai soha többé el nem hagyják." Még munkája 
kezdetén „programot adott” a Néhány szó a fogyatékosok oktatásügyéről címmel az első gyógypedagógiai szakfolyóiratban megjelenő írásában (Náray-Szabó, 1898, 9-10.). Ennek első részében a fogyatékosságok megelőzése, a fogyatékosok számának csökkentése szerepel. A közegészségügyi vonatkozású terveinek lényege: „Profiklaktikus intézkedések foganatosításával apasztassanak a fogyatékosok nagy tömegei”. Azt írja: „Statisztikai adatok bizonyítják ugyanis, hogy a fogyatékos gyermekek legnagyobb kontingensét a legszegényebb néposztály gyermekei képezik, tehát olyan családok gyermekei, amelyekben a közegészségügyi szabályok ellen legtöbbet vétenek... A közegészségügyi viszonyok javulásával a siketnémaság, vakság és hülyeség elterjedése lényegesen megakadályoztatik, míg fordítva a közegészségügyi viszonyok rosszabbodása e fogyatékok számarányát növeli" (Náray-Szabó, 1898, 5.). A fogyatékosság megelőzésére vonatkozó gondolat azután a 20. század első felében, mint a „fogyatékosságügyi társadalompolitika” (Tóth Zoltán, 1933, 215223) első és fö tényezője szerepel, azóta is időről időre orvosi és gyógypedagógusi közleményekben találkozunk vele (Sajnos Tóth ebben a müvében sem Náray- Szabóról, sem az ő 1898-as publikációjáról nem emlékezett meg, irodalomjegyzékéből is hiányzik).

A századforduló társadalmában olyan kérdésekről volt szó, mint a fertőzött vizek, az egészségtelen lakáskörülmények, az „iszákosság” terjedése, a járványok idején való elkülönítés, a védőoltások energikus végrehajtása, a szülésznők körében a Credé-féle eljárás újszülötteknél, a vakság kialakulásának megelőzésére. A vérbaj, valamint a vérrokonság problémái. Harminc évvel később Tóth már kiemelve a házasság és családi élet kérdéseit, kiszélesíti, és elvonatkoztatva tárgyalja a világnézet, a kultúra, és a civilizáció szerepét, a törvényes intézkedések kedvező vagy kedvezőtlen alakulását. A Náray-Szabó által felvetett gondolat így a gyógypedagógiai gondolkodás részévé vált.

Programjának másik része a közoktatás területére utal. Szól az oktatásügy anyagi-financiális hátteréröl. Ez azért jelentős probléma, mert ebben az időben a népoktatási intézmények fejlesztése az állam anyagi erejét „teljesen igénybe vette”. A gyógypedagógiai intézmények pedig akár személyzetben (különlegesen képzett tanerők), kis létszámú csoportok, ahol „,az osztatlan csoportok" müködtetése szóba sem jöhet, (pedig ez abban az időben a népoktatásban igen elterjedt volt), valamint a különleges felszerelése (például mühelyek) jelentősek. Számolni kell azzal is, hogy ebben az időben már a gyógypedagógiai intézetekben az elemi iskolákhoz képest hosszabb volt a képzési idő (8 év). Megállapítja azt is, hogy az amúgy is elégtelen javadalom „elforgácsolván” az oktatásügy bizonyos rendszeres fejlődés helyett stagnált, visszafejlődött, másutt kevés eredményt mutatott. Egyöntetü tervezés, megfelelö tanerők képzése, szakkönyvek kiadása, minden tekintetben megfelelő felszerelés kell tehát, és az új intézetek, iskolák tervszerü fejlesztése. („Az iskolák felállítása bizonyos meghatározott terv és fennforgó szükség szerint legyen elközölhető.”)

A modernizáció főbb beavatkozási pontjai Náray-Szabó szerint: 1) A törvényhatóságok közösen állapítsák meg és jelöljék ki az intézet létesítésére és fenntartására legmegfelelöbb központi fekvésü helyet. 2) Köteleztessenek az egyes törvényhatóságok, hogy az intézet fenntartási és fejlesztési költségeinek hozzájárulását biztosítják. 3) A törvényhatóságok, városok és községek vagyonuk arányában járuljanak hozzá a beutalt tanulók költségeinek fedezéséhez. 4) A közjótékonysági és pénzintézetek kötelességüknek tartsák a humanisztikus ügynek a támogatását. - Az állam vállalja magára a tanerők fizetését, az egyház alapítványok létesítését tartsák feladatuknak.

\section{A fogyatékos gyermekek, tanulók képzésének korszerüsítése}

A siketnémák intézeteiben az élőbeszéd alapján való intellektuális képzés mellett a növendékeket az ipari foglalkozás minden ágára szándékoztak elökészíteni. A vakok oktatásánál is az ipari képzésre helyezték a hangsúlyt az addigi zeneoktatás helyett. Az értelmi 
fogyatékos tanulók esetében nagy változásokat terveztek: ebben az időben már miután államosították (megvették a tulajdonostól) a hülyék és gyengeelméjủek intézetét, a képezhető növendékek nevelését és oktatását újra szervezték. Úgy vélték, a gyengeelméjüek nagyobb számban való oktatása csak akkor valósulhat meg, ha olyanok számára, akiknek internátusi nevelése nem feltétlenül szükséges, elemi iskolákkal kapcsolatosan kisegítő osztályokat és kisegítő iskolákat létesítenek. A dadogók és hebegők számára elemi, polgári és középiskolákkal kapcsolatosan felállított gyógytanfolyamok számát kívánták bővíteni. Külön meg kell említeni a pedagógusok munkája színvonalának emelésére szolgáló törekvéseit: A képzés egyesítése után az iskolákban folyó munka támogatása, a pedagógiai törekvések tudatosságának emelése és a tanulók biztonságosabb megismerése is Náray-Szabó törekvéseinek középpontjába került. Nem véletlenül, hiszen ismerte a századforduló modern pszichológiai és pedagógiai mozgalmait. Érdemes idézni a kiváló gyógypedagógus, pszichológus kortárs, Vértes O. József $(1915,162$.$) szavait: „Náray-Szabó Sándor$ pedagógiája nem esett az egyoldalúság hibájába. A beteg gyermeket, a gyógyító nevelésre szorultakat oltalmába fogadja, de a normális gyermekeket sem téveszti szem elől. A normális gyermekek oktatását, nevelését egészen új pedagógiai alapokra akarja helyezni és ezt az új alapot a gyermektanulmányozásban találja meg." Az a véleménye, hogy a modern pedagógia pozitív eredményeit a gyermektanulmányozásnak köszönheti. (A gyermektanulmányozási bizottság 1903-ban alakult, Náray-Szabó kezdettől részese volt a munkának, 1907-ben a Társaság egyik elnöke lett. Az ott dolgozó kiváló kutatókat, mint Nagy László, Ranschburg Pál, Éltes Mátyás - hogy csak a gyógypedagógiával kapcsolatban állókat idézzük -, személyesen ismerte, támogatta.)

Cikket is ír a gyermektanulmányozás pedagógiai feladatairól (Náray-Szabó, 1914). E téma külön részletes elemzést igényelne, amiről jelen esetben le kell mondanunk. De emlékeztetünk arra, hogy ebbéli törekvései már elöbb, 1902-ben is érvényre jutottak, amikor új típusú intézményt állított fel a magyar tudományos világ számára, a Gyógypedagógiai pszichológiai magyar királyi laboratóriumot, élén Dr. Ranschburg Pállal (Ranschburg Pál a budapesti Pszichiátriai Klinika mellett szervezett kísérleti pszichológiai laboratóriumot 1899 -ben, majd annak jogutódjaként a gyógypedagógiai intézményekhez kapcsoltan mûködõ laboratóriumot Gordosné ezt az időpontot 1906-ra, Vértes O. J. 1902-re teszi. In Vértes O. J., 1915. 160.). Ez az intézmény jogutódain keresztül a magyar gyógypedagógia máig egyik meghatározó intézménye. Sokat tettek a gyermekek jobb megismerésért, akik a társaságban és a laboratóriumban dolgoztak: „Igyekeztünk megállapítani azokat a legalacsonyabb határokat, melyek a normálisok leggyengébbjeit a betegesen gyenge értelmúektől elválasztják" - írta Éltes Mátyás a gyermeki intelligencia vizsgálata könyvének előszavában Ranschburg Pál (1914). Mindketten Náray-Szabó nagy tisztelői közé tartoztak.

A gyógypedagógusok gyakorlati munkáját a már említett szaktanács közremüködésével segítette. Amint Herodek írja emlékirataiban: „Szabályzatok, tantervek, utasítások és egyebek készítése vágtak csapást és mutattak utat a zavarosságban". A szaktanács előterjesztésére, a minisztérium kiadásában 6 iskolai, és két továbbképző, iparos tanonciskolai tantervet adtak ki 1900 és 1910 között. Megjelentettek ún. vezérkönyveket (módszertani szakkönyveket) is, amelyek közül talán a legnagyobb hatású Borbély Sándor munkája (1914).

\section{Az intézetek, iskolák müködésének megújítása}

A gyógypedagógia gyüjtő-elnevezés alá sorolás egy állomás volt a megtervezett úton. Meg kellett erősíteni az együttmüködést, az egyenlő ellátást a különböző szintű munkákban és a különböző fenntartás körülményei között. A minisztérium a kilencvenes évek végéig ún. szakfelügyelőséggel tartotta a kapcsolatot az intézményekkel, Roboz József szakfelügyelőn keresztül. Így elkerülhetetlen volt, hogy gyakran egy személy szubjektív ítélete alapján 
döntsenek intézmények, emberek sorsa fölött. Ekkor jutott Náray-Szabó arra a gondolatra, hogy „a szakemberek elitjéből tanácsot alkosson, amely több realitással és mondjuk, objektivitással intézi az ügyeket" - fogalmazott emlékiratában az események egyik szemtanúja. Náray-Szabó 1898-ban megalkotta a „gyógypedagógiai szaktanácsot”. A szaktanácsba az oktatás minden ágából nevezett ki egy-két pedagógust, s így az egyoldalúságot már eleve is kiküszöbölte ez a nagyobb, szélesebb látókörü bizottság. Az elnöki tisztséget, az irányítást magának tartotta fenn, viszont fontos tisztség volt az előadói, amely a müködést (szervezeti szabályzatot, a tárgysorozatot, az évi jelentéseket stb.) biztosította. Mint Vértes O. József írja, „megingathatatlan elve volt, hogy a különböző gyógyító pedagógiai intézetek müködése között kölcsönhatásnak és harmóniának kell fennállnia. Az abnormis gyerekek ügyei szerinte egységes keretbe foglalandók" (Vértes, 1915, 159.). A szaktanács ülései - írja egy résztvevő - nem sablonos ülések voltak, hanem szőnyegre került minden olyan tárgy, amely az ügyet akár személyi, akár tárgyi szempontból érintette. A szaktanácsi előadó gondos referátumokban terjesztette elő szakvéleményét, amelyhez mindenki hozzászólt. Náray-Szabó mindig részt vett az üléseken, a vitákban. A tanácsot egyéni alkotásának tekintette, nagyra becsülte az ott kialakult véleményt, javaslatokat, demokratikus gondolkodásának ez felelt meg. Sikerült is leszerelni az ellenkezőket, mert látták az eredményeket.

Látta, milyen széthúzó erők müködtek az egyes ágazatokban, és persze az egyéni törekvésekben. De nemcsak papírról intézte az ügyeket, felkereste az intézeteket, iskolákat, hogy tisztázza a gondokat és terveket. A gyógypedagógiai szaktanács fél évszázadon át amíg a háború következményei el nem sodorták - a gyógypedagógusok érdekeinek képviselöje, szakmai irányítója volt, a gyakorlati gyógypedagógia fejlődésének egyik biztosítéka. Jelentései pedig a múlt értékes dokumentumai (a gyógypedagógia történeti feldolgozásának mulasztása, adóssága, hogy e jelentéseket megfelelő történeti elemzések kíséretében nem tették közkinccsé).

\section{A gyógypedagógusok képzésének újjáalakítása}

A századfordulóig a fogyatékos gyermekek nevelői zömében az elemi iskolai tanítókból kerültek ki, és abba az intézetbe, ahol alkalmazták őket két hónaptól két évig tartó külön tanfolyamon ismerték meg a teendőiket. Így ment ez például a siketnéma-intézeti tanárok esetében, 1867-től 1895-ig. De külön tanfolyamok müködtek a vakok és a gyengeelméjüek budapesti intézetei mellett is. Ezt a rendszertelenséget, széttagolást, szétágazódást az egységes vezetés már nem tartotta megfelelőnek. Náray-Szabó javaslatára a miniszter új tanítóképző tanfolyam létrehozását rendelte el, kiterjesztette a vakok, és gyengeelméjüek tanítóira, Vácról pedig Budapestre helyezte át. Ennek az intézménynek tanítási terve, szerkezete, tanítókara Náray-Szabó Sándor nevét külföldön is az első pedagógusok közé emelte - értékeli az átalakítást Vértes O. József professzor $(1915,160$.$) . Ettől a változástól vette kezdetét az$ egységes magyar gyógypedagógus képzés, amelynek történetét Gordosné Szabó Anna 2000ben közreadta.

\section{A gyógypedagógiai intézetek, iskolák fejlődése, a tanárok számának alakulása}

Mint az előzőekben láttuk, Náray-Szabó már 1898-ban kész programmal állt elő, hogy felállítsa hazánkban a különféle fogyatékos gyermekeket oktató és nevelő intézeteket. Határozott elképzelése volt arról, hogyan müködjenek ezek az intézetek, a századforduló legkiválóbb tanárai, igazgatói egyetértésével, támogatásával kezdte meg - közéleti pozícióját felhasználva a hatóságok megnyerésére - a hálózat kiépítését. 
25 éves szolgálati jubileumán, 1912-ben többen emlékeztették az ünnepeltet az elért eredményekre. A legnehezebb feladat és leghumánusabb teljesítmény a méltatók szerint a siketek és vakok elhanyagolt oktatásügyének megoldása volt. Akkor még csak két kialakult intézet - a váci és a budapesti -, valamint két éppen megnyíló - a temesvári és aradi - tudta befogadni az akkori Magyarország területéről a siket gyermekeket. A vak gyermekek számára még csak egy intézet szolgált menedékül, a budapesti. Ebben az időszakban a súlyosabban sérült értelmi fogyatékosok ellátására egy állami kezelésbe vett kis intézet szolgált. A szaktanács jelentéseiből tudjuk, hogy 1910 elejére a hat intézetből 37 intézet lett, amiből 1900 után kilenc intézet a siketnémáknak, nyolc intézet a vakoknak, bennük nemcsak iskolák, hanem ipari foglalkoztató intézetek, öt intézet „szellemi fogyatékosoknak”, gyengeelméjüeknek, öt iskola („kisegítő iskolák”) a gyengetehetségüeknek. Mostani határainkon túl kaptak gyógypedagógiai intézetet Kolozsvár, Temesvár, Arad, Jolsva, Körmöcbánya, Ungvár és Pozsony városok (siketeknek), Kolozsvár, Temesvár a vakoknak. Ez utóbbi két intézet neves gyógypedagógusokat is adott az akkori Magyarországnak. Értelmi fogyatékosoknak Temesvárott és Szatmárban szerveztek intézetet. Meg kell jegyezni azt is, hogy nemcsak iskolákról volt itt szó, hanem a mai értelemben vett szociális célokat szolgáló foglalkoztatókról, sőt egy ápoló intézetről is. Ezek az intézetek mind a vak emberek támogatását szolgálták. A Vakokat Gyámolító Országos Egyesülettel közösen Újpesten 1904-ben létesült az ápoló intézet. Igaza volt Vértes O. Józsefnek (1915), amikor megállapította, hogy NáraySzabó halálával a „magyar gyógyító nevelés története korszakot zárt be, az elemi iskolai gyógyító pedagógia korszakát”. Már életében számos törekvése túlmutatott ezen a korszakon. (A jelen kutatói adósak azzal is, hogy feldolgozzák, elemezzék ezeket a történéseket. Az elméletek, a megemlékezések és „életrajzi gyüjtemények” során túl eljussanak a gyógypedagógiai tevékenység fejlődéstörténetének, a fogyatékos személyek életére ható társadalmieszmetörténeti kutatásoknak a kidolgozására - ezt igényelte már Tóth Zoltán is 1933-ban, 263-266 - ő ide sorolta az intézmények szakmai fejlődéstörténetének, a gyermekvédelem történetének a feltárását. Jelen közleményünkben, ilyen értelemben kezdtünk el foglalkozni a 20. század első évtizedeinek változásaival.)

Berkes János (1910), az újonnan létesült gyógypedagógiai szaktanács előadója közölte a részletes adatokat, bemutatva az évenkénti fejlödést, a növendékeket, az osztályokat, fiú- és lánytanulók számát. 1900-ban 488 siketnéma, 137 vak és 93 értelmi fogyatékos élt az intézetekben, 1910-ben pedig 1871 siket, 628 vak és 556 ,,szellemi” értelmi fogyatékos. (Egy hasonlító szám: Ausztriában, ebben az évben 1509 siket gyermeket tanítottak!)

718-ról 2563-ra emelkedett az ellátott fogyatékos személyek száma, ami több mint háromszoros emelkedés. Lássuk a tanárok számsorait (Magyar Gyógypedagógia, 1910. 38382. Kimutatás.): 1898-ban, az öt intézményben alig félszázan dolgoztak (59 fö), a század tízes éveire ez a szám elért a 170-et, ami hasonlóan háromszoros emelkedés. A már említett egységes, három területre való képzés tovább erősítette a gyógypedagógusok szakmai felkészültségét.

\section{Náray-Szabó munkásságának hatása Szeged oktatásügyére}

A nagyvárosok között Szeged is szerepelt, és viszonylag korán, már 1901-ben létesült a siketek államilag segélyezett intézete (4. kép), majd a szegedi ifjú vakok intézete (1908 - 5 . kép) és végül az Állami Kisegítő Iskola (1913).

A szegedi alapításról és Náray-Szabó közreműködéséről a századfordulón fontos szerepet betöltő Herodek Károly így elékezett meg: „A siketnémák és vakok államilag segélyezett szegedi intézete értesítője néhány lapidáris mondatban megörökítette (Náray-Szabó) tevékenységét, midőn megállapította, hogy különösen előmozdította az intézet létesítésének ügyét, s nemcsak rendkívüli jóindulattal segítette a szegedi intézményeket, hanem 
személyesen is lejött, hogy a még fennálló akadályokat eloszlassa. Ezt az intézetet és annak nagyra becsült és érdemekben gazdag igazgatóját, a mi szeretve tisztelt szakfelügyelőnket, Klug Pétert mindig különös megbecsülésben részesítette, s azért szívesen ragadta meg az alkalmat, amidőn a siketnémák szegedi intézete 10 éves fennállásának évfordulóját ünnepelte, az intézet évfordulóján hitvallást tegyen arra nézve, miként kell az ügyet szolgálni, a szerencsétleneket támogatni, hogy a haza hasznos polgáraivá legyenek".

\section{4. kép: Siketnémák Intézete Szegeden}

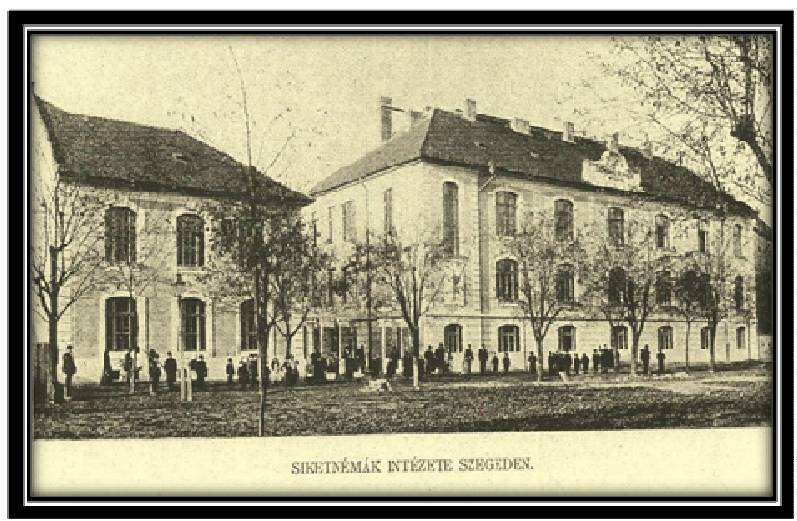

5. kép: Ifjú Vakok tan és nevelöintézete, Szeged

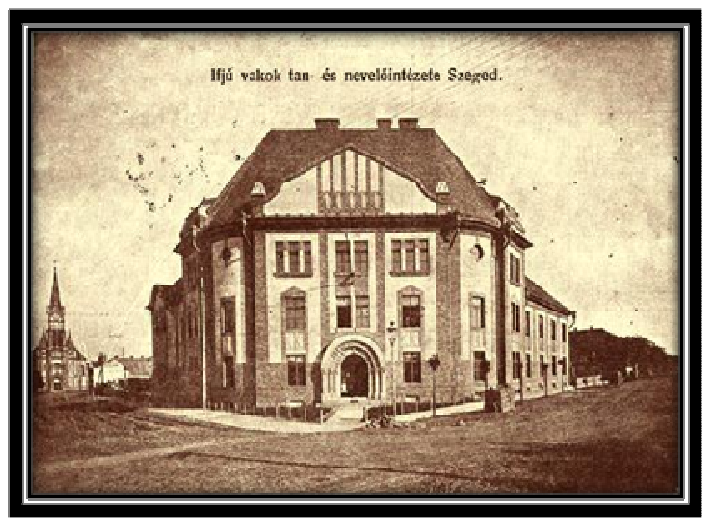

„A humanizmus korunkban” - írta Dr. Náray-Szabó Sándor - „nem öncél, a jótékonyság magasabb szempontjából való eljárást és céltudatosságot igényel. A valódi segítségnek nem szabad pusztán pillanatnyi, közvetlen szükség enyhítésére szorítkozni, egyben kimerülne, hanem vissza is kell adni a fogyatékos érzékủ egyént önmagának. Önbizalmát, önérzetét kell felébreszteni, és táplálni, hogy a tisztességes munka útján való megélhetésre alkalmassá tegyük." Szegeden is megragadta az alkalmat, hogy a tanítóknak elismerését fejezze ki. Megállapította, hogy hazánkban a tanárok és igazgatók vállvetve törekedtek a humanisztikus eszmék népszerüsítésén, nem riadtak vissza az általános tájékozatlanságtól, apostolként 
hirdetik az eszmék megvalósításának fontosságát, azt hogy tanítványaik a társadalom hasznos tagjaivá nevelhetők (Herodek, 1933, 139.)

\section{Siketnémák Állami Intézete Debrecen}

A következőkben Markovics Árpád (1903) igazgató megemlékezéséből idézünk:

Kulturális és emberbaráti feladatát intézetünk az 1928/29. tanévben is zavartalanul erőinek tevékeny megfeszítésével teljesítette. Szeretettel gondozta a kötelékben álló siketnéma gyermekeket és fáradhatatlan kitartással munkálkodott ezek boldogulásának, jövőjének előmozdításán.

A Gyógypedagógiai Intézetek Országos Szakfelügyelösége 884/1928. számú leiratában kijelölte intézetünk körzetét: Hajdú, Szabolcs, Jász - Nagykun, Szolnok, Bihar, Szatmár, Ugocsa, Bereg vármegyéket nevezvén meg, melyeknek területéröl a siketnéma tankötelesek elsősorban intézetünk kötelékébe nyerhetnek, felvételt s a képzés jótéteményében elsősorban részesülhetnek.

A leírtakban foglalt intézkedéshez képest felkérte az igazgatóság nevezett vármegyék törvényhatóság nevezet vármegyék törvényhatósági bizottságait, hogy a tanköteles siketnémák összeírását $\mathrm{s}$ az összesített kimutatásoknak a beküldését rendeljék el. E kimutatások alapján 23 első osztályos és 6 varróiskolai új növendék nyert felvételt, kikkel az intézet növendék létszáma 121-re emelkedett. Sajnos, hogy egyes szülők makacs ellenállása és tudatlanságból eredő elfogultsága e tanév elején is több siketnéma gyermeknek a beiskoláztatását hiúsította meg. Valóban megdöbbentő, hogy amikor az állam, a hatóságok és a társadalom bőkezüsége valamennyi siketnéma tanköteles számára helyet biztosít a nekik emelt intézetekben, a szülők kiskorúsága még mindig útját állhatja annak, hogy siketnéma gyermekük az életnek arról a szánalmasan alacsony színvonaláról, hova a hallás és beszéd hiánya folytán süllyedt, az emberi méltóságot megillető magaslatra felemelkedhessék.

A felvételt nyert siketnéma gyermekek szállást és élelmezést intézetünk internátusában nyernek. Növendékeink közül az év folyamán 115 bennlakó és 6 bejáró volt. A tanévet az elöírt időben, a szokásos keretek között nyitottuk meg. Tanulmányi szempontból a növendékek 2 első, 2 második, 1 harmadik, 1 negyedik, 1 ötödik, 1 hatodik és 1 hetediknyolcadik osztályba osztattak be. Három évfolyamú varróiskolának 17, iparitanonciskolának a varróiskolai növendékkel együtt 24 tanulója volt.

Tanítás. Fő célunk az oktatásnál, hogy a gondozásunkra bízott siketnéma gyermekeket első sorban beszélni tanítsuk meg. A siketnéma gyermeknél a környezetnek nyelvépítő szerepe nincsen. Neki a tanításnak napi 30-40 percnyi ráeső ideje alatt kell beszélni megtanulnia és az élet számára szükséges tudnivalókat elsajátítania. E hihetetlennek látszó feladat munkálása közben ingadozásnak nem lehet helye, miért is intézetünkben a tanítás anyag feldolgozásának rendjét, módját, idejét feltüntetö tanmenetekhez, a tantervben lefektetett kívánalmakhoz igazodva haladt a cél felé. Az osztályok a számukra elöírt anyagot feldolgozták s tartalmi és alaki szempontból jól begyakorolták, különösen a kiejtés tisztasága, a beszéd folyékonysága, érthetősége, terjedelme és az elsajátított szólamok biztos használata tekintetében ért el több osztály figyelemreméltó eredményt.

Nevelés. A nevelés a siketnéma gyermek jövőjére elhatározó, döntő befolyással van. Elszigetelt helyzetéből a siketnémát beszélni tanítás emeli ki és helyezi be a társadalomba. De hogy helyét e társadalomban miként állja meg, az már a nevelés folyamán rágyakorolt hatásától függ. A nevelést az intézet nem kezdi, hanem folytatja ott, ahol a siketnéma gyermeknek az intézmény alá kerülésével a családi nevelés megszakadt. A siketnéma gyermek is teljesít a szülői ház erejét, ügyességét meg nem haladó apróbb szolgálatokat. Ez 
irányú hasznos tevékenykedés folytatásához az intézeti életnek teret kell biztosítania. Ehhez képest nem csak a tanórák, hanem a tanításon kívül eső időben is tervszerüen foglalkoztattuk rendre, tisztaságra, szorgalomra, munkára, önállóságra szoktattuk a növendékeinket.

A növendékeknek állandó helyes irányított foglalkoztatásra és szabadabb mozgásra ad az intézeti nevelésnek, életnek családi jelleget. Teszi a siketnémát fürgévé, mozgékonnyá, jártassá a házi teendők végzésében, ami nemcsak neki személy szerint, hanem az intézetnek is mérhetetlen hasznot jelent.

Intézetünk internátusos berendezése bőven nyújtott alkalmat a növendékeknek a házi teendők gyakorlására. Az intézetünk belső helyiségeiben, udvarán és kertjében észlelhető a pedáns rend és tisztaság jelentékeny részben a növendékek szorgalmas fáradozásának és gondos együttmüködésének köszönhetö.

Az intézetnek természetesen nem csak a növendékek foglalkoztatása tekintetében, hanem egyéb vonatkozásban is pótolnia kell a családot. Nyújtania kell neveltjeinek azokat az apróbb örömöket is, melyekben már a legszerényebb viszonyok között élő család részesíti gyermekeit. Örömet, derüt vittek bele növendékeink életébe a rendelkezésükre bocsátott játékszerek, melyekkel az év folyamán kellemesen elszórakoztak. Enyhébb évszakokban szabadidejüket az intézet tágas játszó- és tornaterén játékkal, tornázással, szabadban való mozgással: játékkal, tornázással, szabadban való mozgással: játékkal, munkálkodással. fürdéssel edzettünk. Testük gondos ápolása, edzettsége mellett súlyt helyeztünk lelkük nemesítésére, hitéletük erösítésére és elmélyítésére is.

Növendékeink hitoktatásban saját felekezetük lelkészeitől részesülnek. A kath. nagyobb növendékek az év folyamán gyóntak, áldoztak, a protestáns nagyobb növendékek konfirmáltak és az Úr asztalához járultak.

Szívükbe oltottuk hazánk, fajunk iránt való szeretetet, törhetetlen hüséget, a jótevők iránti hála, az elhunytak iránt való kegyelet érzését. Isten és a hatalmasok iránt alázatosságra, engedelmességre, egymás között megértő békés magatartás tanúsítására és elözékenységre szoktattuk őket.

Egészségügy. Egészségi állapot szempontjából a tanév nem annyira a növendékeket, mint inkább a tanárokat állította súlyos megpróbáltatás elé. A szokatlanul erős és hosszú tél dacára, növendékeink egészségi állapota semmivel sem volt kedvezőtlenebb, mint az előző években. hülésből eredő bántalmak csak szórványosan fordultak ugyan elő, de gyors és erélyes orvosi intézkedéssel sikerült a bajt minden esetben elnyomni $\mathrm{s}$ járványszerü elterjedését megakadályozni. Szem, orr és garatvizsgálatban többször, röntgenvizsgálatban egyszer részesültek növendékeink az év folyamán. Utóbbi vizsgálatot valamennyi növendékünkön Dr. Geszti József, az Auguszta Szanatórium igazgató-főorvosa végezte; a föorvos úr humánus cselekedetéröl e helyen is köszönettel emlékezem meg.

A megejtett vizsgálatok szerint is növendékeink egészségi állapota megnyugtató volt.

A tanári testület tagjai betegség miatt szokatlanul sokat mulasztottak. Az I.a., II.a., és a III. osztályfőnökei orvosi mütétnek voltak kénytelenek magukat alávetni s a két elöbbi osztályfönökei a tanév második felében nem taníthattak. Másik két osztályfőnökét meg gyermekeink ragályos betegsége gátolta egy ideig abban, hogy az intézetbe bejárhassanak. A mulasztott tanárok helyettesítéséről a testület saját kebelében volt kénytelen gondoskodni, ami órarendünk felforgatásával járt s az osztályok előhaladását visszavetette.

Élelmezés, ruházat. Ellátásban bennlakó növendékeink az intézet internátusában részesülnek. A számukra kiszolgáltatandó ételek minőségét és mennyiségét a 2602/1923. számú min. rendelet szabályozza.

A siketnéma gyermekek hozzátartozóinak nagy szegénysége miatt intézetünkre hárult a feladat, hogy a növendékeket ne csak a képzés jótéteményében részesítse, hanem táplálja és 
ruházza is őket. A szülők rendszerint annyi ruhát hoznak gyermekükkel, amennyi azokon rajta van. Intézetünk tehát kénytelen ruházati cikkekből megfelelő készletet tartani. Növendékeinknek ruházattal való ellátása az év folyamán örvendetesen javult. Alsó-, felsőruha készletünket tetemes költséggel kiegészítettük. Itt említem meg, hogy növendékeink egyenruhái intézetünk varróiskolájában készültek.

Szórakozások, ünnepélyek. Az intézet egész nevelési rendszere a biblia „Ora et labora” kívánalmához igazodik. Növendékeink élete az intézet falai között hasonlatos a kaptár dolgos lakóinak mozgalmas életéhez. Napirend jelöli ki minden órának a tennivalóját, mely tennivalók között szerep jut a növendékek szórakoztató foglalkoztatásának is. Séták, kirándulások, mozi, cirkusz nyújtotta kellemes és hasznos szórakozásban elég sürün volt részük növendékeinknek az év folyamán. Különösen felvillanyozták, élénkké tették a növendékeket az intézetben tartott nyilvános ünnepélyek, melyeknek ők voltak szereplő hősei. Fényes sikerrel járt karácsonyfa-ünnepélyünkről a sajtó meleg elismeréssel emlékezett meg s képeket is közölt. Nyilvános ünnepélyt tartottunk március 15-én nemzeti függetlenségünk, önállóságunk kivívásának emlékére. Nyilvánosan szerepeltek továbbá növendékeink halottak napján, amikor is elhunyt jótevőik sírjánál rövid beszédet tartottak s a sírra virágot helyeztek el.

Kellemes és hasznos szórakozást nyújtott növendékeinknek még a tanév egész folyamán az önképzőkör, melyet Tamás István tanár vezetett.

Az önképzőköri gyüléseken a növendékek újságokat olvastak, megismerték a fontosabb híreket, készültek szerepléseikre, házi újságukat szerkesztették stb.

E helyen örömmel említem még meg, hogy Papp Ferenc és Mán László siketnéma festők spontán elhatározásukból müvészies színpadi díszletet terveztek és festettek intézetünk számára díjtalanul.

Szertár. Intézetünk szertára az év folyamán is minden rendelkezésre állított eszközzel gyarapíttatott. Különösen értékes földrajzi, néprajzi, természetrajzi és természettani képsorozatokkal egészítette ki az intézet szemléltetési eszközgyüjteménye. A szertár gyarapítására az év folyamán 1000 pengöt meghaladó összeg fordíttatott.

Könyvtár. A jó könyvek az elmemüvelése, a lélek nemesítése, a szakbéli ismeretek mélyítése és általában az ismeretszerzés szempontjából nélkülözhetetlenek. Ezért különös gondoskodásunk tárgyát képezte az intézet tanári és ifjúsági könyvtárának újabb müvekkel való kiegészítése. Beszereztük az év folyamán mindazokat az újabb kiadású könyveket, melyek értékes tartalmukkal könyvtárunk hiányait pótolhatták. Könyvtári állományunk az év folyamán 121 kötettel 800 P értékben gyarapodott. Tanári könyvtárunk állománya ez idő szerint 917 mü 1136 kötettel. - Ifjúsági könyvtárunk 328 kötet. Szaporodás 11 mü.

Varróiskola. A varróiskola az intézetet végzett siketnéma leányokat a női szabómesterségre tanítja. A varróiskola kötelékébe felvételt kérő növendékek száma rohamosan növekedik, ami egyrészről ennek az ipari képzést és képesítést nyújtó intézménynek hézagpótló voltát igazolja, másrészről nyomatékosan utal arra, hogy az ipari pályán elhelyeződni kívánó végzett leányok számára tanmühelyek felállítására van szükség.

Varróiskolánk a tanév folyamán üzletkörébe vonta a fiúöltönyök készítését is. Úgy a női ruhák előállításra, mint fiúöltönyök varrása tekintetében a magasabb igényeket is kielégíteni képes. 
A varróiskola növendék létszámának ugrásszerü megnövekedése a felszereléseknek kiegészítését, új varrógépek beszerzését tette elkerülhetetlenné. Helyiségének túlzsúfoltságán pedig úgy enyhítettünk, hogy az intézet árnyas udvarán fedett lugast állítottunk fel, hol a varróleányok az enyhébb évszakokban munkálkodhatnak.

Kertészet. A siketnéma kiskorúak életkörülményeire, leendő pályára való tekintettel az intézeti képzés nem szorítkozhatik csupán az ismeretek közlésére. A növendékeket gyakorlatilag is rendszeresen foglalkoztatni kell erejüket és képességeiket meg nem haladó apróbb munkákkal, melyek testben, lélekben erősítik, többoldalúvá teszik őket.

A kertészkedés, mint a szabadban üzött hasznos és kellemes foglalkozás a siketnémák részére - kik között sok a fejlődésben visszamaradt, gyenge szervezetü, szükmellü, vérszegény, tüdővészre hajlamos - ideális pálya. Intézetünk tágas belsőségén növendékeink a kertészkedésben nagy kedvvel és szeretettel gyakorolták magukat.

A felsőbb osztályos fiú- és leánynövendékeink az intézeti kert müvelésében, a növények gondozásában egyaránt részt vettek. Ily módon képzésük befejezéséig a konyhakertészetben szép jártasságra, sokan közülük teljes önállóságra tesznek szert. Intézetünknek a kertészetből a köztartás számára kiszolgáltatott zöldség- és fözelékféléken kívül az év folyamán 920 P 85 f készpénz bevétele volt.

A 6. kép mutatja be a debreceni intézményt napjainkban.

6. kép: Hallássérültek Egységes Gyógypedagógiai Módszertani Intézménye, Debrecen. Napjainkban

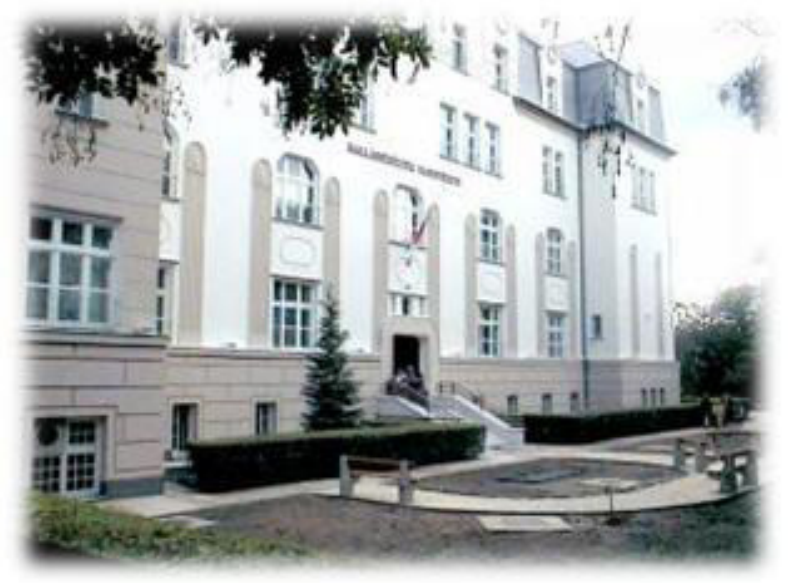

\section{Állami Kisegító-Iskola Debrecen}

A következőkben Vargha Béla (1908) igazgató megemlékezéséből idézünk:

Év végi vizsgáinkat a szülők jóleső elismerése kísérte. Örömtől sugárzó szülői arcok, apák, anyák örömkönnytől ragyogó arcán tükröződött munkánk eredményének elismerése.

Az 1928/29 tanévre az elemi népiskolákból átutalt növendékek megvizsgálását 1928. március 22-től június 10-ig dr. Máday István egyetemi magántanár végezte a tantestület tagjainak segítségével. Elismerésre méltó s fel nem értékelhető az az ügyszeretet és odaadó munkásság, melyet iskola-orvosunk csekély tiszteletdíjáért növendékeink ügyében teljesít, nem díjazásért, de ügyszeretetböl. Budapestről minden csütörtökön leutazik Debrecenbe s az egész délelöttöt, néha délutánt is iskolánkban tölti, időt, fáradtságot nem kímélve. Valóban méltán megérdemelné, hogy az erkölcsi elismerés mellett anyagiakban is munkásságához méltóan díjaztassuk. 
Az elemi iskolák 46 növendéket ajánlottak felvételre. Kisegítő iskolába utalandónak találtunk 36 növendéket, kik közül 30 tényleg a kisegítő iskolába íratott be.

Még mindig vannak szülők, akik idegenkednek gyermeküknek iskolánkban való elhelyezésétől, aminek okát abban látjuk, hogy sok szülő még mindig nem ismeri eléggé az iskola rendeltetését és áldásos munkáját.

A tanévet 1928. évi szeptember hó 6-án nyitottuk meg. Növendékeink, még a nagy távolságról bejárók is, kik a rettenetes hideg miatt sokat szenvedtek, szorgalmasan látogatták az iskolát.

A tanítás menetét semmi sem zavarta február 7-éig, mikor a hideg olyan mérveket öltött, hogy egy héten át 8-9 növendék járt csak rendesen iskolába.

A nagy hideg és a fellépett kanyaró járvány miatt a város polgármestere az iskolákat bezáratta.

Az iskolák február 27-én történt megnyitása után, mivel a hideg még állandóan tartott, a távol lakó növendékekre tekintettel, a tanítást 8 óra 10 perckor kezdtük, s az első órákat 8 óra 10 perctől 9 óráig tartottuk meg.

A szülők gyakran keresték fel iskolánkat s részben gyermekeink haladása iránt érdeklődtek, részben tanácsainkat kérték ki gyermekeikre vonatkozólag és elismerésükkel fokozták a tantestület tagjainak munkakedvét. Az eredmény nem is maradt el, mert a kényszer-szünet ellenére minden osztályban jó eredményt értek el növendékeink.

Az első osztályú növendékeket a) és b) csoportokra kellett osztanunk. Az I.b. osztály vezetésére a kir. tanfelügyelőség vitéz Csillik Györgyné Pityik Irén állami elemi iskolai tanítónőt osztotta be szolgálattételre, ki bár csak október 15-én kezdte meg a tanítást, a több mint kéthetes járványszünet ellenére szép eredményt ért el.

Növendékeink egészségi állapota, - bár a városban a kanyaró járványszerúen lépett fel, teljesen kielégítő volt; csak 5 növendékünk betegedett meg, s a betegségük is enyhe lefolyású volt. Az orvosi segélyre szoruló növendékeket az egyetemi klinikákra küldtük ajánló lapunkkal, hol minden esetben készséggel segítségünkre voltak.

A szegény növendékeket a mulasztási bírságpénzekből írószer, könyv, cipő és ruhasegélyben részesítettük. A róm.-kat növendékek dr. Lakatos Sándor r.-kat. hitoktatónk közbenjárására a r.-kat. egyháznál kaptak jó használt gyermekruhát és cipőt. A városi „Népjóléti Hivatal” 2 gyermeket látott el új cipővel.

A tanév folyamán a rendes iskolai szüneteket megtartottuk. A hazafias ünnepeket helyszüke miatt - csak szerény keretek között ünnepeltük meg.

Iskolánkat a tanév folyamán meglátogatták a Református Tanítóképző Intézet V. osztályú növendékei 1929. február 5-én dr. Novák József és dr. Varga Jenő tanáraik vezetése alatt, március 14-én a Svetits Intézet tanítóképzőjének V. osztályú növendékei igazgatónőjük s két tanárnő vezetése alatt. Mindkét látogató-csoportot úgy a tanítás módszere, mint a növendékek fogyatkozásaira s azok eredetére vonatkozólag Vargha Béla igazgató látta el szakszerü felvilágosításokkal.

Simon József helyettes szakfelügyelö 1929. március 9-én és 11-én tett hivatalos látogatást iskolánkban s az összes osztályok tanítási eredményét megvizsgálta.

A III-ik Gyógypedagógiai országos értekezleten tantestületünk tagjai közül Kelemen Géza, Papp György, Pápay Mihály és Vargha Béla igazgató vettek részt.

Debrecen szab.kir. város Iskolán kívüli Népmüvelési Bizottsága ez évben is iskolánk helyiségeiben tartotta analfabéta és továbbképző tanfolyamait.

Tekintettel a XXII. Országos dalosversenyre, - melynek tartama alatt iskolánknak a „Diósgyőri Jószerencse Dal és Önképző Egylet” 80 tagja volt szívesen látott vendége, - a tanévet június 20-án nyilvános vizsgálattal zártuk be. A vizsgálaton a szülők szokottnál nagyobb számban jelentek meg s jóleső elismeréssel nyilatkoztak tantestületünk szép eredményü munkájáról. 


\section{A fogyatékos személyekről szóló törvény tervezete}

Náray-Szabó együtt érzett és gondolkodott a magyar vezető gyógypedagógusokkal, és együtt alakították a szakma jövőképét. Ezt illusztrálja a fogyatékos személyekről szóló törvénnyel kapcsolatos tevékenysége. A külföldet járó gyógypedagógiai vezetők összegyüjtötték azokat a törvényeket, amelyek más országokban a fogyatékosok nevelését-oktatását biztosították. A törvénytervezethez helyzetképet adtak 18 európai országokból, három fogyatékossági csoport létszámáról, valamint a magyarországi helyzetről, a rájuk fordított költségekről. Minden javasolt paragrafust részletesen indokoltak. E helyütt nem tudjuk bővebben kifejteni ennek az adatgyüjtésnek a teljes tartalmát, bár a 20. században a magyar gyógypedagógia figyelmét mindvégig elkerülte, mert a világháború megakadályozta a tárgyalását (a legfőbb indok: „,erre most nincs pénz” - elvitte a háború). A gyógypedagógia megalapozójának azonban a torzóban maradt tervezet készítése, egyetértésével és támogatásával való közreadása jelentős érdeme. (A kortársak sorra kiemelik személyes részvételét a munkában.) A központi kérdés, ami az évtized során újra és újra felmerült, a tankötelezettség, amelynek 7 éves korban kell kezdődnie és életük 15 éves koráig (vagy ameddig az intézet valamennyi évfolyamát el nem végezte) tartson. Az öt fejezetből és 39 cikkből álló tervezet, benne a tanerőkkel foglalkozó fejezettel, fontos adalék a gyakorlati gyógypedagógia fejlődésének történetében (Törvényjavaslat. Magyar Gyógypedagógia, 1911. 184-188.; Indoklás Magyar Gyógypedagógia, 1911. 245-255.). Feldolgozása és a fejlődés folyamatába való beillesztése szintén adósságaink közé tartozik.

\section{A gyógypedagógia népszerüsítése}

Mint Náray-Szabó programjában említettük, felelősséget érzett abban is, hogy a fogyatékos gyermekek oktatása közoktatásban és a társadalom szélesebb köreiben ismertté váljék, hiszen abban az idöben különösen sok méltatlan támadásnak voltak kitéve nemcsak a kisegítő iskolák, de még a főváros egyik legimpozánsabb épületébe költöző vakok intézete is. Visszaemlékezésekből tudjuk, hogy a pesti bulvársajtó milyen hangon beszélt róluk. De a tájékozatlanság nagy volt a tanítók, tanárok között is. Hiába épültek évről évre újabb intézetek, „fényes paloták”, amelyek befogadták a fogyatékos személyeknek csak egy kisebb hányadát, ha az országban nem volt ismert, kikre, miért költenek ennyit (ami egyébként külföldhöz viszonyítva igen kevés volt), mi lesz ezeknek az embereknek a sorsa. Náray-Szabó fontos elhatározásra jutott, „megindította a gyógypedagógiai könyvtárt, melynek füzeteit mindenfelé terjesztgeti” - írta Dr. Juba Adolf (1902,7-9.) a közoktatási tanács tagja.

A tudományos körök érdeklődését sikerült felkelteni, a híres orvosprofesszor Hőgyes Endre is cikket kért az Orvosi hetilap számára. Igény volt az, hogy a fogyatékosok kérdése, ellátása az orvosegyetemen az iskolaorvosok kurzusaiba beépüljön. De ugyanilyen fontosnak tartották a téma megjelenését a tanító- és tanárképzés keretei közt. Álláspontja volt, „minden modern pedagógusnak ismernie kell a tanulók fontosabb testi és szellemi rendellenességeit, melyek őket előrehaladásukban gátolni képesek" (Náray-Szabó, Bevezető, 3. o., Gordosné Szabó Anna, címszava a Gyógypedagógiai lexikon 38. oldalán). A Gyógypedagógiai Könyvtár közérdekü tudnivalókat közvetített magas szinten, a mai gyakorlatnál sokkal igényesebb tájékozódásban az olvasóknak. Szerzői között olyan neves személyeket találunk, mint Klis Lajos (a siketek), Dr. Sarbó Artur (beszédhibások), Fürj Pál (az ideges és gyöngetehetségü gyerekek), Herodek Károly (a vakok, gyengén látók), illetve Éltes Mátyás (a kisegítő iskoláról, tantervéről). A sorozat 1905-ben már a 6. számát jelentette meg.

\section{Összefoglalás}

Tanulmányunk a 20. századi magyar gyógypedagógia megalapozójáról szól, aki száz éve, 53 éves korában távozott az élők sorából. Dr. Náray-Szabó Sándor neve nem ment feledésbe, megtaláljuk a lexikonokban, gyógypedagógiai tankönyvekben, igaz nagyon elvétve. Életrajzi 
adatait e megemlékezések pontosan felsorolják, kiemelik, hogy a magyar gyógypedagógia egyik kimagasló (nemzetközileg is elismert) képviselöje volt (Gordosné Szabó Anna címszava a Gyógypedagógiai Lexikon 38. oldalán. Budapest, ELTE Bárczi Gusztáv Főiskolai Kar kiadása, 2001.) Az ő elvi megfontolásai alapján kerültek az iskoláskorú fogyatékosok intézményei egységes irányítás alá, létesült a szaktanács, változott a gyógypedagógus képzés, pszichológiai kutató laboratórium létesült. Mindezeket az előzőekben bemutatni kívántuk, azzal a kiegészítéssel, amely a szervezőn, a minisztériumi vezető hivatalnokon túl (aki az intézményi adminisztratív egység létrehozója) volt, a gyógypedagógia nagy müveltségü, széles látókörü, alapos ismerője, fejlődésének irányítója, a gyógypedagógiai gyakorlat megújítója, intézményhálózatának megteremtője, olyan gondolatok elindítója, amelyek később a 20. század folyamán teljesedtek ki. Tisztelettel emlékezünk arra is, amit szükebb pátriánk, Szeged kulturális és iskolaügyében tett, ahogy nemcsak a fogyatékos gyermekek iskoláit, hanem a társadalomba való beilleszkedés (korábban, ahogy szívesen nevezték „boldogulás” - ma egyes esetekben „rehabilitáció”) útját megalapozta. Alkotásai, emléke ma és a jövőben is a magyar gyógypedagógia fontos örökségét képezik. Pótolhatatlan munkája, melyet szigorú következetességgel végzett, útjelzője a gyógypedagógiának.

\section{Irodalom}

Berkes János (1910): A gyógypedagógiai intézetek és növendékek számszerü adatai az 1909. év végén. Magyar Gyógypedagógia, XII. évf. Budapest.

Gordosné Szabó Anna (2000). A magyar gyógypedagógus képzés története. Bárczi Gusztáv gyógypedagógiai Tanárképző Főiskola, Budapest.

Gordosné Szabó Anna (2001): Gyógypedagógiai lexikon. ELTE Bárczi Gusztáv Főiskolai Kar, Budapest.

Herodek Károly (1933): Dr. Náray-Szabó Sándor emlékezete. In: Siketnémák és Vakok Oktatásügye. Budapest.

Herodek Károly (1933): Életem, kéziratos feljegyzések.

Juba Adolf (1902): A gyógypedagógia propagálása. Gyógypedagógiai Szemle, IV. évf. Budapest.

Náray-Szabó Sándor (1898): Néhány szó a fogyatékosok oktatásügyéről. In: Magyar Gyógypedagógia. 1.sz. Budapest. 3-10.

Náray-Szabó Sándor (1909): Bevezető. In: Berkes János (szerk.): Magyar Gyógypedagógia. Budapest.

Náray-Szabó Sándor (1913): Az én tanítóm. Néptanítók Lapja, XLVI. évf. 5. sz.

Náray-Szabó Sándor (1914): A gyermektanulmányozás pedagógiai feladata. A Gyermek. VIII. évf. 2. sz.

Pukánszky Béla és Németh András (1986): Neveléstörténet. Nemzeti Tankönyvkiadó Rt., Budapest.

Ranschburg Pál (1909): Elmélkedések a gyógypedagógia jelenéről és jövőjéről. Magyar Gyógypedagógia 4. és 7. sz. Budapest.

Sándor Pál (1986): Az anekdotázó Deák Ferenc. Magvető, Budapest.

Simon József (1937): Történeti áttekintés a Siketnémák és vakok tanárai 1936-os közgyülésén. Magyar Gyógypedagógia, XXIV. évf. 7-10. sz. Budapest. 106.

Törvényjavaslat. Magyar Gyógypedagógia, 1911. 184-188.; Indoklás Magyar Gyógypedagógia, 1911. 245-255.

Tóth Zoltán (1933): Általános Gyógypedagógia. Budapest.

Vértes O. József (1915): A Gyógyító pedagógia fogalma és köre. In: Magyar Pedagógia.

Vértes O. József (1915): Náray-Szabó Sándor emlékezete. A Gyermek. A Magyar Gyermektanulmányi Társaság közlönye. IX. évf. 5-6. sz. 